\title{
APPENDIX.
}

\section{ON THE CRUSTACEA EATEN BY FISHES.}

I have recognized the following genera and species of crustacea in the stomachs of the fishes of the preceding list, several of them being new to the state. The material afforded has been by no means exhaustively studicd, and the list of species could probably be quadrupled. I have refrained from formal description of some species which are evidently new, preferring to wait for specimens in more perfect condition.

\section{C'ambarus immunis, Hagen.}

This is the only craw-fish I have yet noticed in the stomachs of fishes, and this I have seen but once (in the short-nosed gar), unless young individuals eaten by a small cat-fish (Amiurus melas) also belonged to this commonest of our species.

\section{Allorchestes dentata, (Smith) Faxon.}

Specimens of Lepiopomus pallidus, taken in Crystal Lake, IIcHenry Co., in June, were feeding chiefly on this crustacean. It has also been found in the same species, in L. ischyrus and in Morone interrupta from the Illinois at Peoria.

\section{Crangonyx gracilis, Smith.}

The western form of this species (see Bull. No. 1, p. 6) occurs abundantly throughout central and southern Illinois. It is a very agile and voracious creature, behaving in a jar of entomostraca like a tiger in a sheep-fold. I have noticed that ponds in which it is at all common are nearly or quite destitute of Eubranchipus. The "handiness" with which it uses its anterior feet in feeding is quite amusing. I have found it eaten only by the Top Minnow (Zygonectes notatus.)

Asẹllus intermedius, Forbes.

Eaten by Aphododerus from Union Co. A species of Asellus described by Mr. O. P. Hay, in the paper following this, as A. militaris, has recently been collected in the Illinois River, and has been noted in the stomachs of 
Lepiopomus ischyrus and Eupomotis aureus. Another form which, from its variability, I have not yet ventured to describe as distinct from intermedius, is very common in slow streams and fresh pools in McLean Co., especially in early spring, and bas reached me also from La Salle Co., and from Wisconsin. Its size is equal to that of communis, and it differs from typical intermedius also in the much more robust development of all its appendages, and in the large size of the second joint of the outer ramus of the second genital plates of the male. The form and proportions of these genital plates must be used with caution, howeyer, in describing species, as they evidently vary greatly.

\section{Leptodora hyalina, Lilljeborg.}

This extremely curious crustacean, which may be known by its peculiar, slender form (that of a true cross, the arms of which are the swimming appendages), by its extreme transparency and by the single eye in the front end of its cylindrical head, has hitherto been observed in this country only by Prof. S. I. Smith, by whom a single specimen was dredged in L. Superior in 1871.* It evidently stands between the other Cladocera and the Phyllopoda in many respects, having no slight resemblance to a larval $E u$ branchipus.

It occurs in considerable numbers in Peoria Lake, a mere expansion of the Illinois River, the depth of which does not exceed eighty feet. Specimens taken in a small surface net, in June, 1877, were lost in transit, and it was not again seen until found in the stomachs of Polyodon, Dorosoma and Hyodon. It is not at all certain that this is identical with the European species, all the specimens yet studied being too imperfect to decide this point.

\section{Eurycercus lamellatus, Muell.?}

Specimens apparently of this species appear in the stomachs of fishes from Crystal Lake, McHenry Co., (Apeltes, Labidesthes, Fundulus) and also in shovel fishes from Peoria Lake. It is likewise common in ponds in McLean Co.

Bosmina, sp.?

This genus belongs to a section of Dapniadae (Lyncodaphnia) distinguished by the long and strong anterior antennae and by the reduced importance of the posterior pair. The former are tapering, curved and cylindrical, containing in our species about 14 slightly spinulose joints, with a tuft of bristles on the front of the third) and project from the front of the head like a bifid beak. Occurs in myriads in food of shovel fish, in carp, buffalo, \&c., and in Labidesthes from Crystal Lake.

Ceriodaphnia angulata, (Say) Forbes.

$V$ ery abundant in central Illinois, (McLean and Rock I. counties), but 
not hitherto reported. The following is Say's description, in Jour. Acad. Nat. Science, Phil.. Vol. I, p. 440, 1818 :

"D. angulatu. Body viewed laterally, sub-oval, contracted before, gibbous above near the posterior edge, beneath ventricose in the middle; back sub-ovate, acute behind and contracted before: sides striate with numerous minute, parallel, obliqe lines. Hind edge of the body with a prominent angle in the middle, which is obtuse at tip; above the angle it is siliated. Antennar, 4 filaments on the superior branch, and 5 on the inferior branch; color white or red. Length $\frac{1}{10}$ of an inch. Cabinet of the Academy. Very common in the stagnant marsh water of the forests of the Southern States."

In the Illinois specimens the head is marked off from the body by a dorsal indentation. The color is usually white. Found in the stomachs of carp, buffalo, sun-fish, \&c. It constituted the principal part of the food of a number of croppies taken in April, from the Illinois $\mathrm{R}$. The eggs beneath the carapace were so numerous as to give an orange color to the whole mass of the food at this time.

\section{Daphinia pulex? L.}

The species referred to by Prof. Smith, under this name, * is our commonest Daphnia, occurring everywhere in immense numbers. It is eaten by Polyodon and by many small fishes.

\section{Daphnia galeata, Sars.}

A species probably the same as that figured by Prof Smith in the paper already cited, was found in Crystal Lake,-a shallow sheet of water about 2 miles long-and was eaten in numbers by the abundant little silversides (Labidesthes.)

Canthocamptus illinoisensis, Forbes.

This minute crustacean was frequently found in carp, buffalo and shovel fishes from the Illinois $\mathrm{R}$.

Diaptomus sanguineus, Forbes.

In Pomoxys nigro-maculatus. Numbers of the genus unrecognizable as to species were observed in a variety of fishes.

Many Cyclops and Cypris, the species of which I have not attempted to discriminate, occurred in fishes from all waters and of a dozen families.

* Loc. cit. 